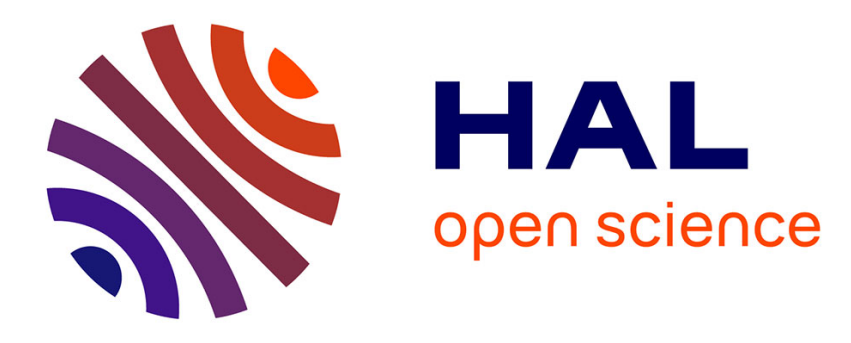

\title{
Monosyllabicization: patterns of evolution in Asian languages
}

\author{
Alexis Michaud
}

\section{To cite this version:}

Alexis Michaud. Monosyllabicization: patterns of evolution in Asian languages. Nicole Nau, Thomas Stolz \& Cornelia Stroh. Monosyllables: from phonology to typology, Akademie Verlag, pp.115-130, 2012. halshs-00436432v3

\section{HAL Id: halshs-00436432 https://shs.hal.science/halshs-00436432v3}

Submitted on 31 Oct 2012

HAL is a multi-disciplinary open access archive for the deposit and dissemination of scientific research documents, whether they are published or not. The documents may come from teaching and research institutions in France or abroad, or from public or private research centers.
L'archive ouverte pluridisciplinaire HAL, est destinée au dépôt et à la diffusion de documents scientifiques de niveau recherche, publiés ou non, émanant des établissements d'enseignement et de recherche français ou étrangers, des laboratoires publics ou privés. 
Published in: Monosyllables: from phonology to typology, ed. Nicole Nau, Thomas Stolz, and Cornelia Stroh, 115-130. Berlin: Akademie Verlag, 2012.

This is a postprint version, with one correction to the references.

\author{
AleXis MiChaUd \\ (LACITO-CNRS, France)
}

\title{
Monosyllabicization: patterns of evolution in Asian languages
}

\begin{abstract}
:
Asian languages reveal a continuum from quasi-disyllables to highly eroded monosyllables. These variegated states are now understood to be different stages along a common evolutionary path. An overview is proposed, beginning with the earliest stages of monosyllabicization, before the generalization of a strictly monosyllabic phonological structure. The well-documented processes of consonantal depletion which lead to the development of phonation-type registers and tones are presented within a general model. Lastly, phonological evolutions observed at advanced stages of segmental depletion are discussed. The concluding note concerns the aftermath of segmental depletion: the recreation of polysyllables.
\end{abstract}

\section{Introduction}

The Far East is famous among linguists for its monosyllabic languages, including national languages such as Vietnamese, Thai and Chinese. However, not all languages of East and Southeast Asia are monosyllabic; indeed, languages that have morphemes of a more complex structure offer irreplaceable insights into the linguistic history of the area. Austroasiatic languages, in particular, reveal a continuum from quasidisyllables to highly eroded monosyllables. These variegated states are now understood to be different stages along a common evolutionary path. A general overview can be proposed, tracing the diachronic developments involved: monosyllabicization, and the avatars of monosyllables as they lose consonantal contrasts and acquire suprasegmental properties.

Such an overview was outlined by A.-G. Haudricourt. However, his talk about monosyllabicization in Southeast Asia was only published in the form of sketchy notes (Haudricourt 1991). Likewise, the remarkable presentation "Evolution vers le monosyllabisme" given by Michel Ferlus at the same forum (the Société de Linguistique de Paris) was only published in the guise of a brief summary (Ferlus 1997). Sections 2 and 3 of the present article draw extensively on these works, with additions based on the latest research results in Sino-Tibetan linguistics. Section 4 discusses evolutions observed at advanced stages of segmental depletion. The concluding note concerns the aftermath of segmental depletion: the re-creation of polysyllables. 
This article aims to be accessible to readers with minimal prior knowledge about the phonological evolution of languages of the Far East. The following subsection (1.1) sets out required background knowledge about sesquisyllables, the type of phonological structure observed prior to monosyllabicization. The last part of the introduction (1.2) sets out the theoretical background to the present research.

\subsection{Monosyllables and sesquisyllables: definition and examples}

A language is said to be monosyllabic if monosyllables serve as the basic structure in the lexicon. In Vietnamese, for instance, the overwhelming majority of morphemes (excluding borrowings) are precisely one syllable long, e.g. sớm $\left[\mathrm{srm}^{\mathrm{B} 1}\right]$ 'early', đi $\left[\mathrm{di}^{\mathrm{A1}}\right]$ ' 'go', có $\left[\mathrm{ko}{ }^{\mathrm{B} 1}\right]$ 'have; exist', or ghế $\left[\mathrm{\gamma e}^{\mathrm{B} 1}\right]$ 'chair' (Thompson 1965, 106; tones are indicated in superscript). There exist lexical polysyllables, but from a phonological point of view they are made out of monosyllables each of which has an independent meaning, e.g. đất nước 'country', from đất

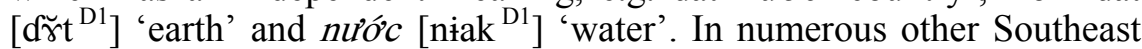
Asian languages, however, there exist more complex structures: Khamou (Mon-Khmer family) has monosyllables, but it also has morphemes such as [kəba:r] 'two', [cəmkin] 'woman', and [rəyko?] 'husked rice'. The latter type of structure is called a 'quasi-disyllable', or 'sesquisyllable': it is "a syllable and a half in length" (Matisoff 1973, 86). The canonical form of a sesquisyllable is the following:

$$
\mathrm{C}_{\mathrm{p}}(\mathrm{V})-\mathrm{C}_{\mathrm{i}} \mathrm{V}\left(\mathrm{C}_{\mathrm{f}}\right) /(\mathrm{T})
$$

This can be divided into a presyllable and a main syllable. The main syllable consists of $C_{i} V\left(C_{f}\right) /(T)$, where $C_{i}$ is an initial consonantal unit (a simple consonant, or a cluster made up of a stop plus a liquid or glide, $/ \mathrm{r} /, / 1 /, / \mathrm{w} /$ or $/ \mathrm{j} /$ ); $\mathrm{V}$ is a vocalic unit; $\mathrm{C}_{\mathrm{f}}$ is an optional, simple final consonant; and $\mathrm{T}$ is a tone. Brackets indicate optional constituents.

The presyllable is $C_{p}(V)$, consisting of a simple consonant, $C_{p}$, plus an optional nucleus, $\mathrm{V}$ : either a vowel, or a sonorant (nasal or liquid) serving as nucleus. In the Austroasiatic domain, the most frequently encountered situation is one in which there can be no vowel contrast in the presyllable: the nucleus consists simply in a schwa, a noncontrastive, optional vowel. In that situation, realizations vary freely between $\left[\mathrm{C}_{\mathrm{p}} \mathrm{\partial}\right]$ and $\left[\mathrm{C}_{\mathrm{p}}\right] .{ }^{1}$

The main syllable within a quasi-disyllable has the same structure as a monosyllable. In the main syllable, all phonological contrasts are found, i.e. the full range of initial consonants, vowels and final consonants. The presyllable can be described as unstressed. It has a simple structure, such

\footnotetext{
${ }^{1}$ The issue has been raised whether sesquisyllabic languages could contrast fused clusters, $\mathrm{CCV}(\mathrm{C})$, and nonfused clusters, $\mathrm{C} \partial \mathrm{CV}(\mathrm{C})$, e.g. /spa/ and /səpa/. To my knowledge, a contrast between fused and nonfused clusters is not found in any of the languages where sesquisyllabic structure can still be observed.
} 
that only the initial consonant needs to be specified (it does not contain any contrastive nucleus); moreover, only a limited range of consonants are found in presyllables.

Some sesquisyllables result from morphological processes, such as the addition of a prefix or an infix to a monosyllable; however, others are not decomposable, so that sesquisyllabic structure cannot be explained away as an expansion of a monosyllabic structure.

At present, the sesquisyllabic type is still widely represented in the Austroasiatic languages. While it is reasonable to hypothesize that sesquisyllables originate in the reduction of earlier 'true disyllables' (morphemes that had two syllables of equal degree of complexity), there is no evidence for such 'true' disyllables in the documented history of Austroasiatic languages, so that the sesquisyllabic stage is commonly taken as the point of origin (terminus a quo) of the process of monosyllabicization. Sesquisyllables are likewise reconstructed in the Tai-Kadai language family (see in particular evidence from the Kam-Sui branch: Solnit 1988). In the Sino-Tibetan family, Old Chinese was a sesquisyllabic language, in the sense described in section 1.1: while one part of its vocabulary was monosyllabic, another part was made up of sesquisyllables (Ferlus 2009, 188 and references therein). However, some present-day languages have polysyllabic roots (e.g. Rgyalrong, about which more below). At the other end of the diachronic evolution, and thus of the typological scale, monosyllabicization has reached a more extreme development in the Yi branch of Sino-Tibetan than within Chinese itself, the language where monosyllabicization arguably began (Ferlus 1997, XVII). The phenomena observed in the languages where syllable erosion has been strongest will be addressed in section 4 .

The following subsection elaborates on the theoretical backdrop to the present work.

\subsection{Usefulness of a panchronic approach to monosyllables}

The present survey adopts the approach advocated under the name of "panchronic phonology" by A.-G. Haudricourt. "In the past century, the comparative method in historical linguistics has improved: we are now in a position to bring out panchronic laws of evolution, to evaluate the degree of probability of various types of changes, and to distinguish parallel variations from common innovations" (Haudricourt 1970, 27; my translation). Panchronic laws are induced from a set of distinct diachronic events, by analyzing individual events in such a way as to bring out their common conditions of appearance. Panchronic phonology attempts to abstract away from specific cases, in order to shed light on the potential for change that is present in a given configuration of a language's phonological structure. The reader is referred to Hagège and Haudricourt 
1978 for examples, and to Mazaudon and Michailovsky 2007 for a discussion that places panchronic phonology vis-à-vis other approaches, such as evolutionary phonology. Monosyllables offer especially fertile ground for a panchronic approach, given the wealth of converging observations that are available for the entire East and Southeast Asian linguistic area.

\section{An overview of monosyllabicization}

The evolution towards monosyllabicity is, at first, a gradual process. The seeds of this evolution can be observed in languages that have disyllabic roots. For instance, within the Sino-Tibetan family, the Rgyalrongic group of languages show evidence of a tension towards monosyllabicization. These languages are more conservative than most Sino-Tibetan languages, and still possess disyllabic roots. Among Rgyalrongic languages, Situ (四土话) preserves polysyllables better than Japhug (茶堡话) and Zbu (日部). For instance, the allomorphic variation of the causative prefix in Japhug shows that it tends to become reduced as prefixed forms become lexicalized. Among its allomorphs, /su-/ is a fullfledged syllable; it is reduced to $/ \mathrm{z}-/$ in front of a derivational prefix that begins with a sonorant (Jacques 2008, 69); /s-/, /6-/ and /z/ are irregular allomorphs, without a regular phonological conditioning. The vowel/w/ has been dropped in some lexicalized items. This is probably related to the prevalence of final stress in Japhug (ibid., 36). Thus, a language can show a tendency towards sporadic monosyllabicization. An important point is that, at this very early stage, monosyllabicization is not simply a phonological process. Lexical frequency plays a role, as does word structure : polysyllabic roots tend to undergo monosyllabicization more easily than words that result from affixation-so long as the various components of the latter remain distinct for the speakers. The prefix /kə-/ found in animal names in Situ has fused with the root in Japhug in the most frequently used animal names, not in other, less common animal names (ibid., 55-56).

Thus, monosyllabicization is, in its first stages, a sporadic process. This has important consequences for later stages, because morphemes which were originally homophonous can come to have different pronunciations depending on the stage at which they undergo monosyllabicization. Supposing, as a theoretical example, a prefixed verb /to-pa/ and a nominal root/təpa/, the noun could become/tpa/ (reduction due to high frequency) while the verb remains /to-pa/; at a later stage, as monosyllabicization becomes systematic, the verb could simplify to /pa/ (through the loss of the presyllable, about which see \$2.1). This makes it especially difficult to reconstruct the past history of languages that are now monosyllabic. 
After a certain amount of time during which monosyllabicization is sporadic, the phenomenon eventually sets in as a hard-and-fast phonological regularity. Systematic monosyllabicization can take place through three processes: (i) loss of the presyllable without any traces; (ii) loss of the presyllable after it has resulted in the spirantization of the medial consonant; and (iii) creation of initial consonant clusters, then of geminated consonants, leading to the development of a tense/lax contrast between former sesquisyllables and former monosyllables. These evolutionary possibilities are presented in the next subsections.

\subsection{Loss of presyllables without compensation}

An important characteristic of sesquisyllables is that the ties between the presyllable and the main syllable are looser than those between segments within a single syllable. Monosyllabicization is a gradual process; a presyllable can become lost without compensation in some lexical items whereas other items remain unaffected. This is not expected in the case of voicing contrasts, for instance: if a language is undergoing a consonantal change which affects the voiced and unvoiced series of initial consonants (a process discussed in section 3.2), it is not expected that the initial voicing of some items will become lost without any traces. On the contrary, a high degree of regularity is expected. On the other hand, loss without compensation (either sporadically, or in all morphemes) is to be expected in the case of presyllables in a language undergoing monosyllabicization. The word for 'tooth' (third item in Table 1) is a case in point. Thavung, Muong and Vietnamese are related languages; Thavung is the most conservative of the three. The Thavung

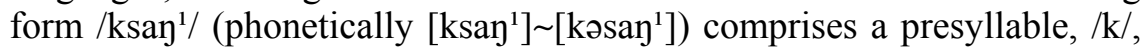
whereas Muong has lost this presyllable. Note that the change from */say/ to $/ \mathrm{t}^{\mathrm{h}} \mathrm{ay} /$ in Muong is not a trace of a former presyllable: the diachronic change $s>t^{\mathrm{h}}$ is general in Muong. In Muong, the loss of presyllables does not leave any traces. "The irregular evolution of presyllables is the main difficulty encountered in the study of phonetic correspondences across Sino-Tibetan languages, as well as in the reconstruction of morphology" (Jacques 2006, 6; my translation).

\subsection{Modification of medial consonants}

The presence or absence of a presyllable may lead to diverging evolutionary paths for the initial consonant of the main syllable, as illustrated in Table 1. Comparison between the closely related Austroasiatic languages Nyaheun and Laven shows that voiced stops that used to be in medial position became devoiced in Nyaheun: the word for 'trough, manger' is /tbo:y/ in Laven, /po:y/ in Nyaheun (Ferlus 1971a). A more complex development took place in Vietnamese: medial consonants became spirantized; later, when presyllables disappeared, this led to a considerable increase in the inventory of initial consonants (Ferlus 1982). 
Table 1. Some cognates between Vietnamese, Muong and conservative Viet-Muong languages, illustrating the loss of presyllables without compensation in Muong and the spirantization of medial consonants in Vietnamese. (After Michel Ferlus, seminar presentation at Université Paris 3, 1996.)

\begin{tabular}{|c|c|c|c|c|}
\hline \multicolumn{2}{|c|}{ cognate in conservative language } & Muong & Vietnamese & translation \\
\hline Thavung & kpui: $^{1}$ & po: $1^{1}$ & vôi [ ${ }^{\mathrm{A} 1}$ voj] & 'lime' $(\mathrm{N})$ \\
\hline Pong & $\mathrm{ktaj}^{2}$ & taj $^{2}$ & dày [ $\left.{ }^{\mathrm{A} 2} \mathrm{zăj}\right]$ & 'thick' (Adj) \\
\hline Thavung & ksay $^{1}$ & $\mathrm{t}^{\mathrm{h}} \mathrm{ay}{ }^{1}$ & răng [ ${ }^{\mathrm{A} 1}$ răy] & 'tooth' (N) \\
\hline Kha-Phong & psu:j $^{3}$ & $t^{h} u: j^{3}$ & rốn $\left[{ }^{\mathrm{B} 1}\right.$ ron] & 'navel' (N) \\
\hline Sách & kcว̀: $\eta^{2}$ & $\operatorname{ciə̀}^{2}$ & giường [ [ ${ }^{\mathrm{A} 2}$ 3ury] & 'bed' $(\mathrm{N})$ \\
\hline Thavung & $\mathrm{cku}^{4}$ & $\mathrm{ku}^{4}$ & gấu [ $\left.{ }^{\mathrm{B} 1} \mathrm{\gamma} \breve{\gamma} w\right]$ & 'bear' $(\mathrm{N})$ \\
\hline
\end{tabular}

2.3. Development of consonantal clusters $>$ geminated consonants $>$ tense/lax contrasts among consonants

A third evolutionary possibility on the path to monosyllabism consists in the creation of consonantal clusters, the consonant of the presyllable clustering together with the initial consonant of the main syllable. Using the abbreviations introduced in $\S 1.1$, where the structure of sesquisyllables was described as $\mathrm{C}_{\mathrm{p}}(\mathrm{V})-\mathrm{C}_{\mathrm{i}} \mathrm{V}\left(\mathrm{C}_{\mathrm{f}}\right) /(\mathrm{T})$, the new clusters consist of $\mathrm{C}_{\mathrm{p}}$ plus $\mathrm{C}_{\mathrm{i}}$. These cumbersome consonantal clusters further evolve into geminated consonants. This stage is illustrated by the Nyaheun word for 'chin', /mma:k/, whose geminated initial is in correspondence with a $/ \mathrm{km} /$ in Laven: /kma:k/ (Ferlus 1971a).

At the stage where presyllables have disappeared, through one of the three processes described above, monosyllabicization is completed. However, the resulting monosyllables are of such a degree of segmental complexity that more changes follow, as consonantal contrasts transphonologize into suprasegmental contrasts. These changes, which result in the present-day physionomy of languages such as Chinese, Vietnamese or Thai, are set out in the next section.

\section{The consonantal depletion of monosyllables and the development} of registers and tones

The development of phonation-type registers and of lexical tones can be considered as an indirect consequence of monosyllabicization. Consonant-replete monosyllables undergo a gradual simplification; lexical contrasts are maintained through the development of suprasegmental properties.

\subsection{An outline of the simplification of rhymes}

The typical order in which segmental simplification takes place within the syllable rhyme is the following (after Haudricourt 1991, with some added explanations suggested by M. Ferlus, p.c.): 
- final /s/, /1/ and /r/ merge with other final consonants: for instance, there occurs a merger of $/ \mathrm{s} /$ and $/ \mathrm{h} /$, without compensation;

- $\quad$ final $/ \mathrm{R} /$ becomes lost, followed by final $/ \mathrm{h} /$;

- final palatals $/ \mathrm{c} /$ and $/ \mathrm{n} /$ merge with final consonants of other points of articulation. This leaves only three points of articulation for finals: labial, apical and velar; and two modes of articulation: stop and nasal (/p/, /t/, /k/, /m/, /n/, /y/);

- the length contrast among vowels becomes lost;

- final stops /p/, /t/, /k/ become lost;

- final nasals $/ \mathrm{m} /, / \mathrm{n} /, / \mathrm{y} /$ become lost, leaving contrastive nasal vowels;

- the nasal vowels merge with oral vowels. ${ }^{2}$

This overall evolutionary pattern is an ideal type: in practice, individual languages may follow somewhat divergent paths, due in particular to contact with neighbouring languages. For instance, final $/ \mathrm{s} /$ merged with $/ t /$ in Pearic languages of Cambodia, instead of following the more common evolutionary path, namely a merger with $/ \mathrm{h} /$.

The second of the processes in the above list leads to the creation of lexical tones: the loss of final $/ \mathrm{l} /$, followed by that of final $/ \mathrm{h} /$, generates, by phonological compensation (transphonologization), a system with three tones, one corresponding to each type of laryngeal plus one corresponding to syllables which were open in the first place (Haudricourt 1954a; Haudricourt 1954b; a recent worldwide survey of tonogenesis, including a review of findings on Asian languages, is proposed by Kingston 2011). An indirect hint about the chronology of events is provided by Middle Chinese: the names given to the three tones of Middle Chinese by contemporary Chinese literati at the beginning of the $6^{\text {th }}$ century CE are "level tone"-from earlier voiced finals-, "rising tone" -from earlier final $/ 2 /$ and glottalized sonorants-, and "departing tone" -from earlier final /h/ (Baxter 1992, 303; Sagart 1999, 93). "It is clear that the denominations 'level' and 'rising' refer to the melody. On the other hand, 'departing', in Chinese qù 去 'to go away, to depart', like its congeneric words qū 祛 'to drive away, to disperse' and qū 呿 'to breathe with open mouth', suggest the idea of expulsion rather than that of melody. Our interpretation is that the description 'departing tone' describes the final spirant $/ \mathrm{h} /$; this implies that the process of tonogenesis by loss of the finals was not yet completed at the beginning of the 6th

${ }^{2}$ This process can occasionally leave traces on initial consonants, witness the Naxi language as spoken in the hamlet of A Ser, where former *hy and *hỹ have become / cy/ and /hy/, respectively, whereas all other syllabic contrasts involving nasal vowels were lost without compensation (Michaud 2006). 
century" (FERLUS 2009: 193). Had the authors of this description wanted to describe a falling tone, they would probably have avoided the word 'under, (go) down' (下; present-day Mandarin Chinese: xià): although it would be a semantically good partner to 'rising', it does not itself constitute an example of the intended tonal category and is thus not mnemonically suitable. However, they could have described the tone as 'falling, descending' (降; present-day Mandarin Chinese: jiàng), which belonged in the tonal category at issue (G. JACQUES, p.c.). The fact that they did not do so confirms Ferlus's interpretation.

Interestingly, Haudricourt did not include in this ordered list the mergers among series of initial consonants, which played a paramount role in the development of tones and phonation-type registers. Indeed, in a general (panchronic) model, there is no reason to place mergers among initial consonants at any special step in the above sequence of events. Mergers between two series of initial consonants can take place at any stage, from stages preceding monosyllabicization -hence the possibility for a sesquisyllable to have a tone on its main syllable, as mentioned in section 1.1- to late stages, when the syllable rhymes have already simplified to a considerable extent. (A case in point in Chinese, which underwent twice a merger among series of initials, at an interval of about 1,000 years: see FERLUS 2009.) For this reason, these mergers are dealt with in a separate section (3.2).

\subsection{Evolutionary paths for contrasts among initials}

In numerous Far Eastern and Southeast Asian languages, an earlier contrast between two series of initial consonants transphonologized into tones; this development is summarized by Haudricourt 1972. However, the creation of new tonal contrasts is only one out of several possible evolutionary paths when earlier contrasts among initials evolve: while these contrasts can turn into tonal contrasts, they can also become vowel contrasts. A unified account can now be proposed for this major panchronic phenomenon: registrogenesis, and its developments (tonal split or vocalic split). Note that the term register refers to phonation-type register, as first described for Cambodian by Henderson 1952. This is a very different notion from the phonological concept of register as a feature of tone; a discussion of the latter notion is proposed in Clements et al. 2011.

The source of registrogenesis is a contrast between two sets of initial consonants. It can be a contrast in mode of articulation: unvoiced $/ \mathrm{p} / \mathrm{g} / \mathrm{t} /$, $/ \mathrm{k} /$ or aspirated $/ \mathrm{p}^{\mathrm{h}} /, / \mathrm{t}^{\mathrm{h}} /, / \mathrm{k}^{\mathrm{h}} /$ contrasting with voiced $/ \mathrm{b} /, / \mathrm{d} /, / \mathrm{g} /$; or glottalised $/ 2 \mathrm{~m} / / 2 \mathrm{n} / / 2 \mathrm{n} /$ contrasting with plain $/ \mathrm{m} /, / \mathrm{n} /, / \mathrm{y} /$. An important addition to the model has recently been proposed on the basis of reconstructions of Old Chinese: a contrast between complex (or 
geminated) and simple consonants could also trigger registrogenesis (Ferlus 2009).

The first stage of registrogenesis is the development of a tense vs. lax contrast between the two sets of syllables, with whispery/lax phonation for the syllables of the 'low' series (those that had voiced initials; or, if the original contrast was one of simple vs. geminated consonants, simple consonants) as opposed to modal phonation for the syllables of the 'high' series. The contrast between modal and whispery/lax phonation is relatively unstable, and tends to evolve into other types of contrasts though transitional stages can occasionally last for centuries.

The synchronic diversity of phonetic correlates of a modal-vs.whispery/breathy phonation-type contrast reveals its evolutionary potential. Observations can be made on languages which currently possess a register contrast. A register system, in its phonological sense, is understood, after Henderson's description (1952), as a prosodic system in which there exists a phonological contrast between phonation types. E. Henderson, describing the phenomenon for a conservative Khmer dialect, speaks of "a normal or head voice quality" as opposed to "a deep, rather breathy or sepulchral voice pronounced with lowering of the larynx" (Henderson 1952, 151). In the Mon language, the vowels of the low series are likewise characterized by a bundle of phonetic features: whispery voice; general laxness of the speech organs; pitch lowering; and a tendency towards the raising of the vowel onset. The term register "describes a cluster of laryngeal and supralaryngeal activities", "one property of which may be dominant and the rest secondary" (Abramson, Thongkum, and Nye 2004, 147). If the pitch differences become dominant, the contrast becomes tonal; if the vowel quality differences become dominant, the contrast becomes vocalic (as is the case in Standard Khmer). The Souei language (a.k.a. Suai, Kuai; Austroasiatic family) has a register system, classically originating in a consonantal mutation; in the variety studied by Ferlus (1971b), this register system is evolving towards a two-way split of the vowel system, as shown in Table 2.

Table 2. Contrasts between the 'high' and 'low' series in Souei, after Ferlus 1979, 4. (Recall that the diacritic/../ indicates breathy voice.)

\begin{tabular}{|c|c|c|c|c|c|}
\hline \multicolumn{3}{|c|}{ high series (proto-voiceless initials) } & \multicolumn{3}{|c|}{ low series (proto-voiced initials) } \\
\hline $\mathrm{i}$ & $\dot{\mathrm{i}}$ & $\mathrm{u}$ & $\underline{i}$ & $\ddot{i}$ & $\underline{u}$ \\
\hline e & $\partial$ & 0 & ie & ia & بِ \\
\hline$\varepsilon$ & $\mathrm{a}$ & 0 & ie & əֶa & רִים \\
\hline
\end{tabular}

Vowels in the low (breathy) series undergo diphthongization, beginning with a lessened aperture. In Souei, vowels in the high series remain unchanged; in other languages, vowels in the high series tend to 
begin with an increased aperture. The reverse is never observed: breathy register never leads to an increased aperture.

The final stage of this vocalic change is a two-way split of the vowel system and a complete disappearance of the other cues to register (pitch differences and phonation-type differences). This stage is observed in Standard Khmer, which is generally described as having five levels of vowel aperture as well as prediphthongization, and no phonation-type contrast (Lewitz 1968; Huffman 1976).

This raises the issue of the factors that determine whether the phonation-type contrast evolves into tonal contrasts or into vowel contrasts. An important factor is whether the language already has tones or not. If not, phonation-type differences eventually tend to stabilize into vowel differences. Such is the case of Khmer. In Mon, where phonation type is still considered to be the primary distinctive cue, differences in vowel quality are already very salient (Lee 1983; Thongkum 1987; Christian Bauer, personal communication). On the other hand, if a language already has tones at the time when the merger of series of initials takes place -or if it is under the influence of a neighbouring language that has tones-, it tends to develop more tones. The phonationtype contrast, which already involved some pitch differences among its phonetic correlates, gives way to tonal contrasts, resulting in a split of the tonal system.

These two evolutionary paths are strikingly illustrated by the different responses given by Chinese to two distinct waves of registrogenesis, the first time at the stage of Old Chinese, the second time at the stage of Late Middle Chinese. Similar causes yielded different effects, because of differences in the language's phonological structure. Old Chinese did not have tones; when registrogenesis occurred in Old Chinese, from the merger of complex and simple initials, it led to a vocalic split (according to the reconstruction proposed by Ferlus 2009, 196). On the other hand, Late Middle Chinese already had three lexical tones (following tonogenesis by laryngeal finals: see section 3.1); when registrogenesis occurred at that stage (from a merger of voiced and unvoiced initials), the language underwent a two-way tonal split (ibid., 195). ${ }^{3}$

\footnotetext{
${ }^{3}$ In the case of Chinese, the hypothesis that a phonation-type-contrast stage must have preceded the tonal stage was already formulated some thirty years ago: “...the split into upper and lower registers was conditioned primarily by the voiced aspiration, giving rise to breathy vowels, rather than simple voice" (Pulleyblank 1978, 173; emphasis added). This hypothesis is now commonly accepted among sinologists. Tamang (Bodic branch of Sino-Tibetan) likewise underwent a two-way tonal split following the merger of voiced and unvoiced initials; to this day, tones 3 and 4, corresponding to syllables that had voiced initials before this two-way split, retain hints of whispery voice (Mazaudon 1977; Mazaudon and Michaud 2008).
} 
Thus, "tonogenesis by the merging of initial series can be seen as a particular case of registrogenesis" (Ferlus 2009, 194). The general theory of registrogenesis as a panchronic process can be considered as a major achievement of historical phonology.

4. Extreme cases of segmental depletion: coarticulation within $\mathrm{CV}$ syllables, and the development of syllabic consonants

Section 2 presented the process of monosyllabicization strictly speaking, which results in complex monosyllables that are especially rich in consonants. Section 3 presented processes of consonantal depletion, with an emphasis on the evolutions leading to registrogenesis and tonogenesis. These are by now well-understood phenomena: in light of the abundant and converging evidence available, a general (panchronic) model can confidently be presented. Later evolutions have been relatively less studied, and remain less well understood. The present section, which discusses evolutions observed at advanced stages of segmental depletion, is therefore exploratory in nature. A full-fledged synthesis concerning the evolution of 'extra-light' monosyllabic structure and monophonemic syllables remains a task for the future.

\subsection{From feature shuffling to coarticulation in monosyllables}

The transfer of a distinctive feature from one phoneme to another within a monosyllable is attested in Southeast Asian languages by synchronic alternations as well as by diachronic evolutions. For instance, the Vietnamese rhymes /oy/ and /oy/ (written as ong and ong) are realized as $\left[\mathrm{ry} \mathrm{g}^{\mathrm{m}}\right]$ and $\left[\Lambda \mathrm{y}^{\mathrm{m}}\right]$, respectively: lip rounding, originally a feature of the vowel, is realized as final rounding on the coda (Thompson 1965, 1991:12; Henderson 1985, 21). This is referred to as "feature shuffling" by Eugénie Henderson (ibid.). In syllables that are already very simple in structure, tending towards a CV (consonant+vowel) segmental structure, there is little room for feature shuffling. Instead, the consonant and vowel paired together in CV sequences become strongly coarticulated; their features tend to be realized all across the syllable.

Numerous examples are found in the Yi (Lolo) branch of Sino-Tibetan languages: while the impetus for monosyllabicization can safely be hypothesized to have come from Old Chinese, which influenced -directly or indirectly- languages of the Sino-Tibetan, Tai-Kadai, Hmông-Miên and Austroasiatic families, segmental depletion has reached a more extreme development in Yi than within Chinese itself (Haudricourt 1991). The tendency towards coarticulation in CV monosyllables tends to create compact units that become less and less tractable to a straightforward analysis into two distinct phonemes. For instance, in Naxi, a Sino-Tibetan language geographically and typologically close to Yi/Lolo languages, the vowel [0] only appears after retroflex consonants: thus, there are 
syllables that are pronounced [lo] (e.g. 'bone') and syllables pronounced [lo] (e.g. 'work, toil'), but no [lo] or [lo]. Indeed, the only context in which retroflex consonants appear is in front of [0] (Michaud 2006). The phonemic solution adopted consists in analyzing [0] as an allophone of /o/, and granting phonemic status to retroflex initials; however, in such extreme cases of neutralization, a potential for coalescence is clearly present. A look at dialectal diversity reveals that this potential is realized in Yongning $\mathrm{Na}$, a close relative of Naxi: the cognate of Naxi 'bone' /lo/ in Yongning $\mathrm{Na}$ is $/ \tilde{\mathrm{l}} /$, i.e. a syllable consisting of one single phoneme, a nasalized syllabic retroflex approximant (Michaud 2008). Unlike CV sequences, this syllable does not require any movement of the articulators in the course of its production: there is one single articulatory target for the entire syllable.

Syllabic nasals can also be interpreted in this light. "In various Loloish languages some or all of the nasals occur as syllabics. In most such cases the diachronic source is syllables with a nasal initial and a high vowel; sometimes one dialect has nasal syllabics where others have nasals plus a high vowel. This could be called rhyme-gobbling" (Bradley 1989, 150; see also Björverud 1998, 8). An intermediate stage is illustrated by Yongning $\mathrm{Na}$, where the syllable $/ \mathrm{mv} /$ is phonetically realized as [m] except in careful (hyperarticulated) speech.

4.2. Quasi-monophonemic syllables: the example of vowel apicalization

"Apical vowels" are the most widespread example of quasimonophonemic syllables. They are syllable rhymes that are homorganic with a preceding apical sibilant (fricative or affricate consonant). For instance, in Naxi, the word for 'wine' can be approximated phonetically as [ $\mathrm{z}_{\mathrm{b}}$, 'meat' as [ $\mathrm{sz}_{\mathrm{l}}$. The vowels that are susceptible to apicalization are high vowels, be they front vowels or back vowels; apical vowels may be allophones of different high vowels in different languages. In Naxi, they are allophones of $/ \mathrm{w} /$, conditioned by initial apical sibilants (He Jiren and Jiang Zhuyi 1985, 9); in Chinese, they are allophones of $/ \mathrm{i} /$, in the same context. Phonetically, no difference was observed in the realizations in these two languages; for instance, the syllable [sz] is interpreted phonemically as /si/ in Chinese, as /su/ in Naxi. In this sense, apicalization is a process close to "rhyme-gobbling" by initial nasals (presented in the previous paragraph).

Specialists of Chinese, a language that has apical vowels, have proposed that the rhymes in these syllables should be recognized as vowels in their own right, distinct from the initial, and represented by special symbols. The full set of symbols used by Karlgren 1915-1926 consists of a plain apical vowel [1], a retroflex apical vowel [ ?], a rounded plain apical vowel [ $૫$ ], and a rounded retroflex apical vowel [૫] 
(see Pullum and Ladusaw 1986; Zee 2008). Naxi 'wine' would then be represented as [zi], 'meat' as [ Sq]. These four symbols have not yet been taken up in the International Phonetic Alphabet, precisely because they refer to articulations for which consonantal symbols exist: the first two correspond to $[z]$ and $[z]$, respectively; for the latter two, a diacritic can be added to indicate lip rounding: $[\mathrm{z}]$ and $\left[\mathrm{z}_{\mathrm{l}}\right]$.

One of the reasons why apicalization is common in monosyllabic $\mathrm{CV}$ units is because palatalization -an especially common phenomenon cross-linguistically - tends to feed into apicalization (Baron 1974). The degree of complexity that can be attained as a result of these developments has sometimes been underestimated: for instance, it has been stated that " $/ \mathrm{q} /$ and $/ \mathrm{y} /$ can combine phonetically with $/ \mathrm{ts} /, / 1 /$ as

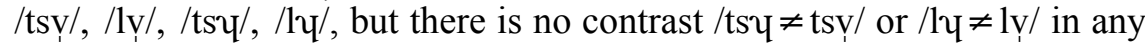
one language" (Baron 1974, 3). In fact, the Laze language, another close relative of Naxi, does contrast /tsv/, /tsy/ and /tsi/, corresponding phonetically to [tsy], [tsq] and [ts]], respectively (Michaud and Jacques 2012).

\section{Concluding remarks}

\subsection{The re-creation of disyllables by compounding}

Monosyllabicization and the ensuing simplification of syllable structure result in homophony of numerous morphemes that were previously distinct: the new contrasts that arise -tones, new vowel contrasts, or new series of initial consonants- compensate only in part for the loss of earlier contrasts. Disyllables then tend to develop anew, by the combination of two monosyllables one of which may come to serve as a type of affix. Like the process of reduction of sesquisyllables to monosyllables (\$2), the creation of disyllables affects the vocabulary gradually. The newly created disyllables are at first no more than an occasional association of two monosyllables; as their association becomes more frequent, the speakers' awareness of their compound status decreases, up to the point where the disyllable is no longer perceived as a combination of two identifiable components. In Yongning $\mathrm{Na}$, 'egg' is /Læ..6 /, clearly created by the association of $/ \mathrm{LM}^{\mathrm{L}} \mathfrak{x} /$ 'chicken' to an earlier monosyllable /ьү/ meaning 'egg', for which there are cognates in Naxi and Laze, two closely related languages. However, the disyllable is now fully lexical, and refers to any type of egg, not simply chicken eggs: 'cane egg' is /M ${ }^{\mathrm{M}}$ b.mi ${ }^{\mathrm{L}}$ æ.

The words for 'calf', 'mare' and 'stallion' in Yongning Na illustrate different stages along the path towards full lexicalization. (About the notation of tones in the following examples, see section 4 of Michaud 2008.) 'Calf', $/^{\# \mathrm{H}} \mathrm{Zw} æ . z 0 /$, literally means 'baby horse': it is made up of

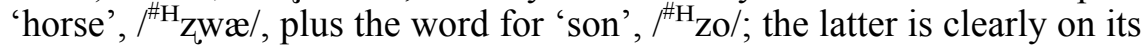


way towards becoming a mere suffix, but at present its grammaticalization is still at an early stage. In the word for 'mare',

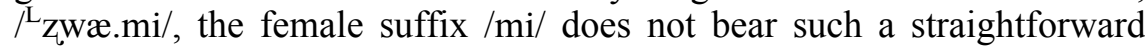
relationship to a given monosyllabic noun, though this suffix is clearly related to the classifier $/ \mathrm{L} \mathrm{mi} /$, used for some animals, which itself is probably related to the $/ \mathrm{mi} /$ element in /L mi.zu/ 'woman' and /Mo.mi/ 'mother'. The association of the two elements making up the morpheme 'mare' must be of some historical depth, since the tone pattern of the disyllable is not as expected on the basis of synchronic rules. Synchronically, the female suffix $/ \mathrm{mi} /$ appears to be toneless, and the tonal pattern of the resulting disyllable is obtained by association of the tone of the root with the entire disyllable (ibid., 192); in the case of 'mare', one would expect a ${ }^{{ }_{\mathrm{H}}}$ tone, not a ${ }^{\mathrm{L}}$ tone. Lastly, 'stallion', $\mathrm{ML}_{\mathrm{ZWW}}$.su/, is yet further advanced towards independent existence as a disyllabic unit: while its first syllable can still be identified as the root for 'horse', its second syllable is neither an identifiable monosyllabic noun or adjective, nor a productive affix.

5.2. An open question: why sesquisyllables were widespread in East Asia (prior to monosyllabicization)

The above analyses brought out evolutionary similarities across three East and Southeast Asian language families -Sino-Tibetan, Austroasiatic and Tai-Kadai-, from a sesquisyllabic state to a monosyllabic state. Monosyllabicization is thought to have begun in Old Chinese, and to have spread across East and Southeast Asia through the influence of Chinese. It is thus an areal phenomenon in East and Southeast Asia; this echoes observations made about the "areality of monosyllabicity" in the languages of Europe (Stolz 2007). The spreading of this phenomenon over a large part of the East Asian mainland was made possible by the typological similarity in phonological structure across these language families prior to monosyllabicization, viz. the existence of sesquisyllables. Monosyllabicization mostly affected languages that already had a sesquisyllabic morpheme structure, i.e. a structure which is intermediate between a full-fledged disyllable and a monosyllable. Polysyllabic languages neighbouring on Chinese (e.g. Altaic languages) remained unaffected. This raises the diachronic issue of why the sesquisyllabic type was widespread in East Asia (prior to monosyllabicization). Sino-Tibetan, Austroasiatic and Tai-Kadai being distinct language families, ${ }^{4}$ how come languages of these families had strong similarities in syllable structure at an earlier stage of their history? In the present state of our knowledge,

\footnotetext{
${ }^{4}$ The existence of apparent cognates across language family boundaries have led to several attempts at different groupings, but these examples are most likely to be due to substratum effects; the classification adopted here classically recognizes Sino-Tibetan, Tai-Kadai, Austroasiatic and Austronesian as distinct language families.
} 
only speculations can be offered about these developments, which predate the earliest linguistic records.

\section{Acknowledgments}

Many thanks to Michel Ferlus, Guillaume Jacques, Martine Mazaudon, Boyd Michailovsky, Laurent Sagart and Jacqueline Vaissière for precious comments and suggestions. Needless to say, I alone am responsible for remaining shortcomings.

\section{References}

Abramson, Arthur S., Therapan L. Thongkum, and Patrick W. Nye. 2004. "Voice Register in Suai (Kuai): An Analysis of Perceptual and Acoustic Data." Phonetica 61 (23): $147-171$.

Baron, Stephen P. 1974. "On the Tip of Many Tongues: Apical Vowels Across SinoTibetan." 7th International Conference on Sino-Tibetan Language and Linguistic Studies.

Baxter, William H. 1992. A Handbook of Old Chinese Phonology. Trends in Linguistics Studies and Monographs 64. Berlin: Mouton de Gruyter.

Björverud, Susanna. 1998. A Grammar of Lalo. Lund: Lund University.

Bradley, David. 1989. "Nasals and Nasality in Loloish." In Prosodic Analysis and Asian Linguistics: To Honour R.K. Sprigg, ed. David Bradley, Eugénie J.A. Henderson, and Martine Mazaudon, 143-155. Canberra: Pacific Linguistics C104.

Clements, Nick, Alexis Michaud, and Cédric Patin. 2011. "Do We Need Tone Features?" In Tones and Features, ed. Elizabeth Hume, John Goldsmith, and W. Leo Wetzels, 3-24. Berlin: De Gruyter Mouton.

Ferlus, Michel. 1971a. "Simplification Des Groupes Consonantiques Dans Deux Dialectes Austroasiens Du Sud-Laos." Bulletin De La Société De Linguistique De Paris 66 (1): 389-403.

1971b. "La Langue Souei $\square$ : Mutations Consonantiques Et Bipartition Du Système Vocalique." Bulletin De La Société De Linguistique De Paris 66 (1): 378-388.

1979. "Formation Des Registres Et Mutations Consonantiques Dans Les Langues Mon-khmer." Mon-Khmer Studies 8: 1-76.

1982. "Spirantisation Des Obstruantes Médiales Et Formation Du Système Consonantique Du Vietnamien." Cahiers De Linguistique - Asie Orientale 11 (1): 83-106.

1997. “Compte Rendu D'exposé: Evolution Vers Le Monosyllabisme Dans Quelques Langues De l'Asie Du Sud-Est." Bulletin De La Société De Linguistique De Paris 92 (1): XVII-XVIII.

2009. "What Were the Four Divisions of Middle Chinese?" Diachronica 26 (2): 184-213. 
Hagège, Claude, and André-Georges Haudricourt. 1978. La Phonologie Panchronique. Paris: Presses Universitaires de France.

Haudricourt, André-Georges. 1954a. "De L'origine Des Tons En Vietnamien.” Journal Asiatique 242: 69-82.

1954b. “Comment Reconstruire Le Chinois Archaïque." Word 10 (2-3): 351-364. 1970. "Les Arguments Géographiques, Écologiques Et Sémantiques Pour L'origine Des Thaï." In Readings on Asian Topics $\square$ : Papers Read at the Inauguration of the Scandinavian Institute of Asian Studies. Scandinavian Institute of Asian Studies Monograph 1, 27-34. Lund: Studentlitteratur.

1972. "Two-way and Three-way Splitting of Tonal Systems in Some Far Eastern Languages (Translated by Christopher Court)." In Tai Phonetics and Phonology, ed. Jimmy G. Harris and Richard B. Noss, 58-86. Bangkok: Central Institute of English Language, Mahidol University.

1991. "La Monosyllabisation Et L'apparentement Des Langues Du Sud-Est Asiatique." Bulletin De La Société De Linguistique De Paris 86 (1): XX-XXI.

He Jiren, and Jiang Zhuyi. 1985. Naxiyu Jianzhi (A Presentation of the Naxi Language). Beijing: Minzu Chubanshe.

Henderson, Eugénie J.A. 1952. "The Main Features of Cambodian Pronunciation." Bulletin of the School of Oriental and African Studies 14 (1): 149-174.

1985. "Feature Shuffling in Southeast Asian Languages." In Southeast Asian Linguistic Studies Presented to André-G. Haudricourt, ed. Suriya Ratanakul, David Thomas, and Premsrirat Suwilai, 1-22. Bangkok: Mahidol University.

Huffman, Franklin E. 1976. "The Register Problem in Fifteen Mon-Khmer Languages." In Austroasiatic Studies. Oceanic Linguistics Special Publication No 13, ed. Philip N. Jenner, Laurence C. Thompson, and Stanley Starosta, 575-589. Honolulu: Hawaii University Press.

Jacques, Guillaume. 2006. "La Morphologie Du Sino-tibétain." In Journée D'étude "La Linguistique Comparative En France Aujourd'hui”, 4 Mars 2006, Ecole Des Hautes Etudes En Sciences Sociales. Paris: http://halshs.archivesouvertes.fr/halshs-00173948/.

2008. Research About the Rgyalrong Language (嘉线语研究). Beijing: Minzu Chubanshe.

Karlgren, Bernhard. 1915. "Etudes Sur La Phonologie Chinoise." Archives D'études Orientales $15(1-4)$

Kingston, John. 2011. "Tonogenesis.” In The Blackwell Companion to Phonology, ed. Marc van Oostendorp, Colin J. Ewen, Elizabeth Hume, and Keren Rice, 23042333. Wiley-Blackwell.

Lee, Thomas. 1983. "An Acoustical Study of the Register Distinction in Mon." UCLA Working Papers in Phonetics 57: 79-96.

Lewitz, Saveros. 1968. Lectures Cambodgiennes. Paris: Adrien-Maisonneuve.

Matisoff, James A. 1973. "Tonogenesis in Southeast Asia." In Consonant Types and Tones, ed. Larry M. Hyman, 71-96. Southern Californial Occasional Papers in Linguistics $\mathrm{N}^{\circ} 1$. Southern California Occasional Papers in Linguistics 1.

Mazaudon, Martine. 1977. "Tibeto-Burman Tonogenetics." Linguistics of the TibetoBurman Area 3 (2): 1-123. 
Mazaudon, Martine, and Boyd Michailovsky. 2007. "La Phonologie Panchronique Aujourd'hui: Quelques Repères." In Combats Pour Les Langues Du Monde: Hommage à Claude Hagège, ed. Jocelyne Fernandez-Vest, 351-362. Paris: L'Harmattan.

Mazaudon, Martine, and Alexis Michaud. 2008. "Tonal Contrasts and Initial Consonants: a Case Study of Tamang, a 'missing Link' in Tonogenesis." Phonetica 65 (4): 231-256.

Michaud, Alexis. 2006. "Three Extreme Cases of Neutralisation: Nasality, Retroflexion and Lip-rounding in Naxi." Cahiers De Linguistique - Asie Orientale 35 (1): 23 55.

2008. "Phonemic and Tonal Analysis of Yongning Na." Cahiers De Linguistique - Asie Orientale 37 (2): 159-196.

Michaud, Alexis, and Guillaume Jacques. 2012. "The Phonology of Laze: Phonemic Analysis, Syllabic Inventory, and a Short Word List.” Yuyanxue Luncong 语言 学论从.

Pulleyblank, Edwin G. 1978. "The Nature of the Middle Chinese Tones and Their Development to Early Mandarin.” Journal of Chinese Linguistics 6: 173-203.

Pullum, Geoffrey K., and William A. Ladusaw. 1986. Phonetic Symbol Guide. Chicago \& London: The University of Chicago Press.

Sagart, Laurent. 1999. "The Origin of Chinese Tones." In Proceedings of the Symposium "Cross-linguistic Studies of Tonal Phenomena: Tonogenesis, Japanese Accentology, and Other Topics”, ed. Shigeki Kaji, 91-104. Tokyo: Tokyo University of Foreign Studies, Institute for the Study of Languages and Cultures of Asia and Africa.

Solnit, David B. 1988. "The Position of Lakkia Within Kadai." In Comparative Kadai: Linguistic Studies Beyond Tai, ed. Jerold A. Edmondson and David B. Solnit, 219-38. Summer Institute of Linguistics Publications in Linguistics, 86. Dallas: Summer Institute of Linguistics and the University of Texas at Arlington.

Stolz, Thomas. 2007. "Being Monosyllabic in Europe: An Areal-typological Project in Statu Nascendi." In Linguistics Festival: May 2006, Bremen, ed. Andreas Ammann, 97-134. Bochum: Universitätsverlag Dr. N. Brockmeyer.

Thompson, Laurence C. 1965. A Vietnamese Reference Grammar. Vol. [1991 edition]. Washington: University of Washington Press.

Thongkum, Therapan L. 1987. "Another Look at the Register Distinction in Mon.” UCLA Working Papers in Phonetics 67: 29-48.

Zee, Eric. 2008. “Phonetic Characteristics of the Apical Sounds in Chinese.” In 第八届中 国语音学学术会议 (8th Phonetics Conference of China), (Full-paper proceedings published on CD-ROM, without page numbers). 北京 (Beijing), April 18th-20th 2008.

\author{
ALEXIS MiCHAUD \\ LACITO-CNRS \\ 7 rue Guy Môquet
}


Alexis Michaud

94800 Villejuif, France

alexis.michaud@vjf.cnrs.fr 